\title{
Studies on Total Logistics Management in Physical Distribution Process"
}

\author{
Jin-Hwan KIM \\ Professor, Department of International Trade, Korea National Open University, Seoul, Korea . \\ E-mail: jhkimkp@knou.ac.kr
}

Received: November 19, 2019. Revised: December 10, 2019. Accepted: December 12, 2019.

\begin{abstract}
Purpose - The purpose of this paper is to examine total logistics concept performed by $3^{\text {rd }}$ party logistics, managing with 4th party logistics to achieve more efficient and systematic dealing with sub-functions of physical distribution process.

Research design and methodology - The research method to be adopted is first to review 3th party logistics providers that has attracted to various functions of $4 \mathrm{PL}$, and then total logistics concept to be investigated which is related to $3 \mathrm{PL}$ and $4 \mathrm{PL}$.

Results - For the total logistics concept implemented by 3PL, management technique should be widen, then 3 PL's service activities and area should extend. Especially for the collaboration effects between the company and external organizations, it can be collaborated with some commitments in terms of their own independent activities, carrying on inherent functions by both 3PL and 4PL, pursuing total logistics concept.

Conclusions - More areas of logistics service has been required by clients in the field, and service activities available is strongly related to roles of 3 th party logistics providers as main player in logistics market. However, total logistics management is could be implemented by 3PL combining with various functions of logistics service offered by 4 th logistics provider.
\end{abstract}

Keywords : 3th party Logistics, 4th party Logistics, total logistics management, logistics provider, outsourcing.

JEL Classifications Code: L14, L22, L24, R40, R41.

\footnotetext{
${ }^{*}$ This research is fully supported by Fund of Korea National Open University (2019.03-2020.02).
} 


\section{Introduction}

The global logistics market in its present state has come about as a result of an amalgamation of supply side and demand side trends. The rapid proliferation of trade agreements among various nations is the major demand driver of the global logistics market. Additionally, the initiatives aimed at increasing globe trade activities have expanded the demand for logistics in order to keep pace with the rising needs of importers and exporters (Research \& Markets, 2019).

Today, company has kept on improving through technological advancements with infrastructure and record keeping. As time has gone by, so has the importance of logistics, in fact this progress has strongly related to warehousing and other facilities closer to large towns and cities. Logistics is influencing businesses within towns and cities, making more jobs into these locations. Accordingly logistics is an important part of the supply chain. It manages the effective forward and reverse stream of goods and services origin to consumer. This means that logistics is a matter of the shipment of goods and how quickly they can deliver to the consumer. The direction of third party logistics (3PL) is on the rise.

It has been newly spread trend of logistics services that total logistics management is one of alternatives which 3 PL can take advantage of external organization with 4PL in the physical distribution process, giving service user like shipper better logistics services. From the shippers' point of view in terms of commercial transaction, it is directly connected with their competitive strategy that is to outsource something not to be able to insource like distribution and logistics matters. Therefore, it is natural for service users to look for better logistics services provided by 3PL.

However, it is clear that collaboration has been all the time appeared in the process of physical distribution to seek better logistics management. It could be understandable matters which is pursuing cost down and looking for effective way of logistics management. Shipper has always looked for better way of distribution activities and answer is coming out from contacting out with external entity, which interface third party logistics provider that is combined with fourth party, providing total logistics management.

This paper have examined into total logistics in terms of positive collaboration that is connected 3PL with 4PL, offering both more synergic power and effective way in order to achieve the logistics goals. Some difference with other research that has mainly focused on combined and comprehensive approach of all logistics parties to explain total logistics management is that this study is especially concentrated with 3th party logistics to define total logistics management, connected with 4th party logistics. As far as its expandability of this study is concerned, this study will help the field to apply and exercise in their work flow.

However, it structured as follows. First, looking for 3th party logistics in various points, and second 4th party logistics provider, and third the characteristics between 3PL and 4PL should be described, and then total logistics management is stated with some important tools, and finally implications is given in conclusion.

\section{Third Party Logistics}

\subsection{A Brief History}

There has been four or fifth party logistics that are working in the market spread in physical distribution industry. First stage of logistics and supply chain management activities is that both transport and production were done by one producer, then it has separately divided in some business activities in terms of insourceing and outsourcing, which the latter is given to 3th party logistics providers. Historically, some phases can be categorized into each generations.

As for beginning stage of 3th party logistics in 1980s, some companies has set up to provide services functions both transport and storage, and information technology widely spreaded produced room for 3th party logistics companies. These companies basically lifted a certain of burden from manufacturing or producing companies related to supply chain management. Accordingly, it has correlated with number of companies and number of trucking carriers, which is using third-party logistics services.

It is 1990s period that logistics industry has boom stage according to demand of outsourcing with third party logistics in emerging economies. As a result, the need for companies capable of supply chain processes has rapidly risen in both domestically and globally. Furthermore, third-party logistics services led to some companies specializing in niche markets - like frozen food products and construction industries - offering vehicles and facilities capable of handling the purchasing of a company's specific needs (Berglund, et.al.,1999).

The 2000s is strongly connected with the global internet environments. Technologically advanced innovations 
have given to 3th party logistics providers, which play a role to make streamline complex communications and supply chains. As far as third party logistics is concerned, it has to be specialized with a certain area of job related to export and import management such as transportation operation and some other activities like inventory management, order processing, and worldwide demand for 3PL has resulted in many companies to save money on fuel cost, in favoring of their customers. In this regard, technological advancements could be emphasized with business processes that company as well as 3PL can modernize their entire systems, which gives their customers to fulfill their needs. Accordingly it is connected with time, money and competencies on advanced technological logistics systems.

\subsection{Definitions of Third Party Logistics}

Many definition of third party logistics has been described in various meanings related a lot of elements of the supply chain, which belongs to outsourcing activities and providers about logistics, distribution, transportation and product consolidation, etc. Third party logistics is the function by which the owner of goods usually shipper outsources to 3PL company that can carry on operations activities of the client's inbound freight, customs, warehousing, order fulfillment, distribution, and outbound freight to the clients customers. Furthermore, a thirdparty logistics provider is a company that offers a service packed to its clients of outsourced (or third party) logistics services for part or all of their supply chain management functions.

\subsection{Function of 3PL}

Outsourced logistics services of a third-party logistics provider can be supplied to companies in need of supply chain management of goods to be distributed (Iqbal \& Dad, 2013). These services can make up part or sometimes all of their supply chain management functions as table. 1, including :

Table 1: Function of 3PL

\begin{tabular}{|c|c|}
\hline Inventory storage and management & Picking and packing \\
\hline Freight forwarding & Shipping/distribution \\
\hline Customs brokerage & Contract management \\
\hline IT solutions & Cross-docking \\
\hline Consolidation & Insurance \\
\hline
\end{tabular}

Source : made by author

In a business deal, compatibility is the main basis for selection (Tu, 2016). Similarly, when selecting a service provider, not only efficiency of the service matters but whether it is needed or not matters too.

In order to utilize functional advantages on the logistics process, selection to right 3 PL provider is key factor to make a successful outsourcing. The manufacturing company requires to concentrate on acquiring a appropriate logistics solution by outsourcing rather than only taking into account how good the services are (Srishti \& Nasina, 2019). In the modern global environment, companies has two logistical goals which have not only fostered service quality, raising the efficiency, and they also reduced the expense by means of third-party logistics (3PL). 3PL, therefore, is an important strategy for companies anticipating a competitive advantage and selection of 3PL provider plays a decisive role about the goals for outsourcing (Ecer, 2018). In spite of that, the degree of uncertainty in the selection process is relatively high and asked to be cautiously taken into account.

\subsection{PL Companies}

There are famous companies to provide third party logistics, and actually these companies have offered all the functions as stated in function of 3PL, which manages and operate on the global basis, as like UPS. However, Amazon gets along with restrictions related to packaging requirements and allowable products, more services are limited than some other 3PL. 3PL is acceptable to small-to-medium-sized of companies running businesses that expect to take advantage of the managerial power of an external logistics companies, but still want a certain level of control over their supply chain management (Agburu et al., 2017). In terms of field commitment, the third party logistics provider has actively got involved into actual jobs, but these can be divided into merits and demerits. 
As far as merit of 3PL is concerned, first, It works well with both local and international distribution, and shipper can get speedier delivery by benefiting from their multiple storage locations, second, it works well for a fast growing business with large order volumes, third, to find the right 3PL can save shipper's time and money, through economies of scale (eg. shipping rates), and then it is easy for shipper to control customer service and returns. However, as for demerits of 3PL, first, 3PL can be an expensive cost, especially when shipper only has small quantities of orders, second, shipper has less control over their inventory and the customer experience, third, it is sometimes time consuming to find the right provider who shipper can trust and rely on, finally, 3PL providers won't handle perishable, hazardous, or flammable goods in general terms.

\subsection{Present 3PL Situations}

The situations fluctuated with demand of products annually require companies to be flexible approaches to deal with their distribution management (Hansen, et. al.,2008). Therefore, company to outsource some activities in supply chain management to $3 \mathrm{PL}$ means that company to improve efficiency and to cut cost. In this regards, the role of 3PL in present time has to be emphasized in terms of saving a money which 3PL gives a chance to company to access technological tools and to make best decisions for their functional activities of supply chain management (Giustiniano \& Carli, G.L, 2013).

\subsubsection{Cost Matters}

It is very important to acknowledge cost side of logistics management for all the parties got involved in this business. Business has always been concerned with money matters which is related to company's profitability. As far as 3PL is concerned, company has to decide something cost effective in their distribution activities. Company has to look for services and to utilize logistical functions provided by 3PL operators that belong to lager companies and enterprises in the early times.

Many 3PL providers have entered in the market as the demand of functional services has grown over the years, which makes all sizes businesses possible to cost-effective solutions available. By increasing their transportation and warehouse capacity, 3PL providers make smaller businesses that asked to outsource a certain level of activities in their supply chain management process and logistics, by lowering their rates and providing cost-effective solutions.

\subsubsection{On-Demand Service}

3PL providers is providing their brokage and flyer services of on-demand transportation in recent time, which has become an indispensable capability for 3PL operator who has provided basic counterplan to successfully logistics solution of supply chain management. The expenses charged to clients regarding to on-demand services are based on particular conditions and availability, and could be different from general published rates remarkably.

Today on-demand service has become a popular niche market that provides 3PL more monetary return than their regular services. These services include full truckload (FTL), less-than truckload (LTL), direct and exclusive transport services, the next flight out service, fast delivery, and expediting a delivery anywhere in the world. By ondemand transportation services, 3PL plays acting role in brokerage between their customers and the companies. Job description includes that broker 3PL offers to sell unsold goods throughout their call center and, in feedback, ask a high margin of about 15 percent on every sale achieved. In this case, 3PL doesn't take the obligation to make a sale all the goods, however this gives the irregular consignor chance to sell their products suitably.

\subsubsection{Niching Down}

3PL provider has entered into niche business activities, which makes a profitable outcome on their company records. Niche 3PL providers have developed their expertise in different ways. 3PL can select to concentrate on either offering best services or move to geographical place in favor of their customers. However, many 3PL niche down into the particular industry straight with which their business processes best align.

These niche 3PL providers make solutions on all side of higher value and better care for the commodities they have stored and loaded. They can take advantage of conventional systems and processes to rationalize procedures for their network of clients. The experiences 3PL provider's team has carried out are applied to similar solutions for similar kinds of goods. Additionally, niche 3PL providers also have the benefit of being able to provide tailoredmade solutions to their clients. It is possible for niche 3PL to take a view of cooperation with their clients by providing particular solutions in defined industry circles. 3PL can fulfill demand of increasing market and 
continuously developing requirements of their customers between existing systems and specialized teams of 3PL.

\subsection{The Future of 3PL}

As growing demand of 3PL services in the field, The 3PL industry is rapidly developing at the outsourcing markets which have a potential possibilities to increase demands of promoting companies by providing clients more managerial control and visibility over their supply chains processes. Companies offering 3PL services can take advantage of own key competencies. 3PLs have been evolving from tactical service providers to collaborative partners that are keen to take on more responsibility. These 3 th party logistics providers have also concentrated on fostering decision-making process that is data-driven and offering logistics services that is solution-oriented, to further enhance supply chain functions of their customer.

\section{Fourth Party Logistics}

\subsection{Definition of Fourth Party Logistics}

The 4 party logistics is defined in various interpretation of meanings of the literature, and it has classified and summarized in table 2. Functionally, 4PL is a supply chain model that combines with 3PL-based capital, consulting, and other resources in order to manage and apply these resources (Kao, et al., 2019). In this case, outsourcing activities should be needed, and trend from insourcing to outsourcing in supply chain process of company has remarkably appeared step by step.

Arrangement in which a firm contract out (outsources) its logistical operations to two or more specialist firms (the third party logistics) and hires another specialist firm (the fourth party) to collaborate the activities of the third parties. For instance, logistics services in Europe have changed from market transactions to outsourcing to warehouses and contractors, then to the current 3PL and 4PL. From insourcing to outsourcing, third-party goods has provided to service process, and 4PL could be the next key and important wave in the industry after 3PL. Therefore, a wide and useful area of services could be offered for clients, and specialization in ranges of these services must be set up. These roles are an important procedure for the switched from 3PL to 4PL (Kao, et al., 2019).

Table 2 : Definition of 4PL

\begin{tabular}{|c|l|}
\hline Reference & \multicolumn{1}{|c|}{ Definition } \\
\hline $\begin{array}{c}\text { Bade and } \\
\text { Mueller, } \\
(1999)\end{array}$ & $\begin{array}{l}\text { The 4PL service providers offer services that can provide technology and integrate 3PL } \\
\text { organizations. }\end{array}$ \\
\hline $\begin{array}{c}\text { Copacino } \\
(2001)\end{array}$ & $\begin{array}{l}\text { Ideally, 4PL must establish a high level of IT and logistics analysis capabilities, such as the } \\
\text { ability to provide supply chain information visibility, enhanced efficient supply chain planning, } \\
\text { and optimal and efficientb execution capabilities to achieve the position of a supply chain leader. }\end{array}$ \\
\hline $\begin{array}{c}\text { Huang } \\
(2001)\end{array}$ & $\begin{array}{l}\text { The core competencies of 3PL operators are largely focused on the logistics capabilities of the } \\
\text { transportation and warehousing departments. Here, 4PL aims to improve the effectiveness of } \\
\text { enterprise supply chain management by integrating the services of multiple operators to provide } \\
\text { different values for each link of the supply chain. }\end{array}$ \\
\hline $\begin{array}{c}\text { Magill } \\
(2000)\end{array}$ & $\begin{array}{l}\text { 4PL provider and its customers are in partnership with each other to provide integrated logistics } \\
\text { services. Together, they also manage and optimize the overall supply chain with operational and } \\
\text { strategic logistics-related activities. }\end{array}$ \\
\hline
\end{tabular}

Source: Bade and Mueller(1999), Copacino(2001), Huang(2001), Magill (2000).

\subsection{Area of Fourth Party Logistics}

A fourth-party logistics provider essentially takes third-party logistics a step further by managing resources, technology, infrastructure (Saglietto, 2013), and even manage external 3PLs to design, build and provide supply chain solutions for businesses. 
4PL services typically includes 3PL services as well as:

- Logistics strategy

- Analytics including transportation spend, analysis, capacity utilization, and carrier performance

- Freight sourcing strategies

- Network analysis and design

- Consultancy

- Business planning

- Change management

- Project management

- Control tower and network management services, coordinating a wide supplier base across many modes and geographies

- Inventory planning and management

- Inbound, outbound and reverse logistics management

\subsection{PL examples}

4PL services is much more related to conventional 3PL by providing strategic business competences and special services for consulting together with additional logisitcs activities. It is also reviewed in terms of merits and demerits of 4PL. As for merit of 4PL, it can contract out and outsource whole segment and process of business logistics including distribution activities, and in addition to operational support, take advantage of strategic advice as well. As far as demerit is concerned, it takes a little control over processes that has implemented in the logistics activities. It is also said it likely to be expensive one. The 4PLs is relatively new concept developed in logistics markets, and it is applying to businesses from medium to large sized that are looking for a perfect logistics solution in terms of both managerial and a tactical perspective.

\section{The Characteristics between 3PL and 4PL}

\subsection{Differences}

Many experts in supply chain industry have discussed the difference between 3PL, 4PL and other 'PL, and a lot of logistics provider provides many aspects of logistics serviced got involved in the supply chain process, comparing the past (table. 3). However, best services to be defined depends on business model, budget, infrastructure, and how much control to be possible by service users. However, many businesses in eCommerce select with 3PL, which is able to offer an excellent collaboration with support, flexibility, and cost-effectiveness.

4PL and 3PL has some different characteristics between each others, that is exclusive entity, combination, and 3PL's initiatives, which explains its differences as follows, First the 4PL organization is often a separate and independent structure established by a joint venture or other long-term contract between a client and one or more partners, second, the 4PL organization is a connection between the customer and multiple logistics services providers, third, the 4PL organization has managed total sides of customer's supply chain in ideal terms, and then fourth, it is possible for a major 3PL organization to set up a 4PL organization among its established structure.

The competence of 4PL to consolidate is in a more excellent manner than that of 3PL, regarding to services, features, organization, and positioning, as table 3 illustrates. 4PL includes multiple logistics service providers and involves all degrees of job in the supply chain, compared with 3PL (Hingley, 2011). Thus, the cross-functional capability of integration is asked for 4PL in multi-customer and supply chain management. As far as logistics operations are concerned, 4PL not only holds of 3PL's characteristics but also owns great degrees of responsibility and management that 3PL does not possess.

Table 3 : Comparison between 3PL and 4PL

\begin{tabular}{|c|l|l|}
\hline Category & \multicolumn{1}{|c|}{$3 \mathrm{PL}$} & \multicolumn{1}{|c|}{$4 \mathrm{PL}$} \\
\hline Service & $\begin{array}{l}\text { Intended mainly for transportation and } \\
\text { warehousing services }\end{array}$ & $\begin{array}{l}\text { Capable of handling all supply chain level } \\
\text { operations }\end{array}$ \\
\hline
\end{tabular}




\begin{tabular}{|c|c|c|}
\hline Positioning & $\begin{array}{l}\text { Insufficient cross-functional integration of } \\
\text { various operational capabilities within the } \\
\text { supply chain }\end{array}$ & $\begin{array}{l}\text { Integrator of supply chain elements between } \\
\text { multiple logistics service providers and the main } \\
\text { consignor }\end{array}$ \\
\hline Organization & Provider of professional logistics service & $\begin{array}{l}\text { An independent entity arising from a joint } \\
\text { venture or long-term contract between the } \\
\text { principal and a partner }\end{array}$ \\
\hline Features & $\begin{array}{l}\text { Combines analytical management with IT to } \\
\text { streamline the process by omitting } \\
\text { unnecessary processes and reducing costs }\end{array}$ & $\begin{array}{l}\text { Apart from combining the technologies and } \\
\text { resources of } 3 \mathrm{PL}, 4 \mathrm{PL} \text { promotes highly efficient } \\
\text { supply chain management to create higher added } \\
\text { value }\end{array}$ \\
\hline
\end{tabular}

Source : Huang et al. (2008), Cheng et al. (2008) \& Dollet \& Diaz (2011)

\subsection{Model of 3PL and 4PL}

\subsubsection{Third Party Logistic Model (3PL)}

The producer or manufacturer contract out a bundles of transport and distribution activities within logistics services provided. The third party provider of logistic services has organised these activities and may employ third parties for the specific subsequent commitment (subcontracting). This service provider sometimes happens to make a contract not just with the manufacturer, but also with the supplier. As the third party logistics provider, it becomes to organize the logistics activities between these two consecutive performer in the supply chain management.

\subsubsection{Fourth Party Logistic Model (4PL)}

Fourth party providers of logistic service often examine the whole supply chain process (Skender, et. al., 2017). In terms of outsource logistics tasks from third parties, the manufacturer or supplier contract out the organization as well as the management of third parties. The organizational and managing activities are sometimes outsourced to other parties again.

Fourth party providers of logistic service often have no means of transport and warehouses (non-asset based logistics), as contracting carrier of third party logistics providers. The 4 th party logistics provider has been demanded great connection with the service suppliers in the business and management activities of customers. After all, it belongs to outsourcing and monitoring activities in logistics processes, which makes parties involved be satisfied with their business. In a first stage, collaboration agreements is strongly related to cost aspects $(\mathrm{Li}, 2014)$, and then it has been replaced with partnerships of service quality, which is prime role and best in long terms strategy later.

\section{The Total Logistics Concept}

\subsection{Five Logistics Service Providers}

It has been classified into five different layers in terms of logistics service providers, and according to market situations of outsourcing activities, scope of logistics provider is more specifically divided and developed $<$ Table $4>$. At the present market situations, third party logistics (3PL) provider is emphasized, relating to other providers. 
Table 4 : Meaning of Logistics Provider

\begin{tabular}{|c|c|}
\hline Logistics Provider & Meaning \\
\hline First party logistics (1PL) & $\begin{array}{l}\text { companies that provide transportation of certain goods or use specific shipping } \\
\text { methods to transport goods in a certain geographic area. Port operators and } \\
\text { depot companies are good examples of 1PL providers. }\end{array}$ \\
\hline Second party logistics (2PL) & $\begin{array}{l}\text { companies that transport goods in a larger national geographical area than 1PL } \\
\text { companies. They offer their own (and external) logistics resources including } \\
\text { trucks and warehouses. Some examples of } 2 \mathrm{PL} \text { providers include parcel } \\
\text { services, freight forwarders and ocean carriers. }\end{array}$ \\
\hline Third party logistics (3PL) & $\begin{array}{l}\text { quite similar to } 2 \text { PLs with the key difference being that 3PLs offer additional } \\
\text { value added services like warehousing and packaging in addition to being } \\
\text { integrated into the customer's system. This way, they're informed about the } \\
\text { expected workload in the near future rather than being on call. }\end{array}$ \\
\hline Fourth party logistics (4PL) & $\begin{array}{l}\text { no own transportation assets or warehouses. Instead, they have an allocative } \\
\text { and integration function within the purchasing company's supply chain. } \\
\text { Simply put, 4PL providers work as intermediaries between purchasing } \\
\text { companies and 3PL providers with a goal to help the purchasing company } \\
\text { increase supply chain efficiency. }\end{array}$ \\
\hline Fifth party logistics (5PL) & $\begin{array}{l}\text { helping their customers implement the latest technologies in their supply chain } \\
\text { activities. The main purpose of a 5PL service provider is to provide system } \\
\text { oriented consulting and supply chain management services to purchasing } \\
\text { companies. }\end{array}$ \\
\hline
\end{tabular}

Source: Giustiniano \& Carli (2013)

\subsection{Collaboration}

The total logistics concept (TLC) has dealt with the many different parts of broad category of distribution and logistics under one single integrated system (Ploos van Amste \& Verstegen, 1991). Inter-relationship between different elements should be emphasized, aiming to outcome from logistics process combined each other. There are 4 different levels of collaboration have been identified. However, these collaboration could be offset by effective approaches to achieve rationalization of logistics activities in terms of unitization and optimization. But No.4 belongs to something different compared with other 3 cases, which means it results synergic outcome in view of total logistics concept.

\subsubsection{Within Distribution Components}

Those collaboration that takes place within functions in one in the middle of interested parties related to manufacturers, suppliers, distributors, and consumers. The first of these providers offer to better warehouse space utilization, even more difficult for picking. The second one is convenient for picking, however not provide such good warehouse space utilization.

\subsubsection{Between Distribution Components}

Those collaboration among the different factors in distributions. It begun from the supplier that deal with a product then forward to the manufacturer. The manufacturer will sell product by encouraging it. Next, the distributor will supply for sale or take the product to the end users. Lastly, the consumer will pay for and use the product to satisfy their demands and meet their expectation.

\subsubsection{Between Company Functions}

Collaboration can be appeared with several of areas in terms of interface between functions in the company. It is possible for economies of scale to lower unit cost and more cost-effective production, but it means that more 
products could be kept for a longer period which is less cost-effective for warehouse space utilization. Here, each departments of a company could collide with their own inherent functions. In wider sense, the company should follow the rank of management and its functions.

\subsubsection{Between The Company and External Organizations}

Where a collaboration may be beneficial for two companies that are connected with each other. The two companies have aim specific and single goals and act together but both parties do their own independent activities, carrying on inherent functions.

\subsection{Tools of Total Logistics Management}

\subsubsection{Rationalization}

The rationalization of logistics transportation is to ensure the quality of transportation, with the appropriate means of transportation, the least number of transportation links, and the best transportation route, on the premise of ensuring the flow of goods to a reasonable flow. The minimum cost of transportation brings the goods to their destination. Its significance is reflected in the following aspects (Aoteshu Packing, 2019).

(1) rationalization of logistics transportation can make full use of transportation capacity, improve transportation efficiency, promote rational division of labor among various modes of transportation, minimize labor consumption of social transportation, and meet the transportation needs of the national economy in a timely manner.

(2) rationalization of logistics transportation can enable goods to take the most reasonable route and reach their destination with the shortest mileage in the fastest possible time through the least number of links, thus speeding up the circulation of goods and providing the market in a timely manner, It can also reduce the circulation cost of the material department, accelerate the turnover of funds, reduce the bad goods and gain good social and economic benefits.

(3) the rationalization of logistics transportation can eliminate all kinds of waste phenomena in transportation, improve the quality of commodity transportation, give full play to the efficiency of transportation means, and save transportation capacity and labor force. Otherwise, unreasonable transportation will cause a lot of human, material and financial waste, and correspondingly transfer and add to the product, artificially increase the value of the product, increase the price of the product, thereby increasing the burden on the demand side.

\subsubsection{Unitization}

Unitization is essentially grouped or bundled cargo, wrapped into packages and loaded onto or inside a bigger unit. These bigger units can then be handled by machines such as forklifts and cranes. Because of the bigger size, the number of individual units to be loaded on the ships reduces; saving time and effort, increasing efficiency and lowering the chances of late deliveries. Some of the benefits of unitization are as follows (BlueWhale, 2019):

(1) The efficiency of cargo handling increases as heavier units can combine many smaller packages into one large package.

(2) The safety of cargo increases as cranes are used to lift the load vertically upwards using slings. The slings can be made strong enough to withstand loads several times more than the load being lifted. Previously the cargo had to be carried manually by individuals or lifted up using pulley and rope; many a times this resulted in cargo getting damaged.

(3) The labor required is reduced drastically, thus resulting in cost saving.

(4) The loading and unloading time reduces. Ships, trucks, railway wagons have to wait idle for lesser duration. The time spent by ships at ports is reduced to a great extent, making voyages shorter.

The disadvantage is that many unskilled and semi-skilled labors lose their job. The working environment changes and earlier employees and their work become vague. The most common form of unitization is palletization. The forklifts and cranes are designed to handle certain dimensions of package. The pallet is made to this dimension and acts as a platform for cartons and boxes to be stacked on top of it. The entire pallet then becomes a single unit with the cargo secured tightly onto the pallet base. The materials for pallets can be hard wood, soft wood, steel, plastic 
and even fiber board depending on the voyage, type of safety required and reusability.

The next big step in unitization was containerization. It all began as noble idea of a US based businessman Malcolm Mclean, who modified a Second World War tanker vessel to carry boxes known as containers. The vessel was named Maxton and began sailing in the year 1956. The cargo would be loaded into these boxes, which were capable of being placed directly onto the trucks. This saved a lot of time compared to break-bulk carriers. The ship was modified to carry 60 such boxes as deck cargo. By 1970s, container shipping started getting a boost from Europe and Japan, and the rest of the world soon followed suit.

\subsubsection{Hub and Spoke Network}

A hub and spoke network is a centralized, integrated logistics system designed to keep costs down. Hub and spoke distribution centers receive products from many different origins, consolidate the products, and send them directly to destinations. The hub-and-spoke model creates numerous benefits, including (PENSKE, 2019):

(1) Continuous movement for loads thanks to centralized handoffs.

(2) Reduced lengths-of-haul, which improve scheduling, reduce transit time and help drivers comply with hoursof-service regulations.

(3) Consistent on-time performance, which enhances service levels and ensures products arrive in the right place at the right time.

(4) Improved driver recruiting and retention. Drivers are able to return home each night, thus experiencing an improved quality of living. This produces additional benefits, including higher tenure, route consistency, increased transit dependability and performance, and improved safety.

(5) Reduced costs and enhanced productivity thanks to Penske's economies of scale (larger loads reduce per-unit costs) and the elimination of the need for team drivers.

(6) Lower carbon footprint, because few empty miles driven reduces wasted fuel and emissions.

(7) Consistent pricing mitigates the risk of third-party carrier price fluctuations.

\section{Conclusions}

\subsection{Summary}

According to shipper requirement has developed, the 3PL industry has evolved into a essential options of outsourcing for general firms that struggle to look for operational efficiencies in logistics and supply chain management. In this sense, 3PL providers has provided customers better visibility related to distribution activities, with total logistics management with 4 th party logistics.

Here, 3th party logistics provider as well as 4th party logistics provider has been studied in various view of approaches, especially 3PL is main player in logistics activities first of all, then two parties has been compared with each other in their characteristics. However, the part that is witnessed in this paper is total logistics management suggesting some tools of achieving efficient management of logistics goals. Therefore, this is main point should be focused in this research.

\subsection{Implications}

In order to materialize total logistics activities, the role of 3th party should be emphasized in various terms, therefore 3th party logistics provider can play a important roles in the logistics market. Shipper has outsourced their non-core competence like transport functions in physical distributions process, which third party logistics provider should play their inherent roles and services. May be total logistics management could be answer to this matter, which means 3PL can extend their basic and necessary services of logistics activities, combining with 4th party logistics equipping with their different functions.

To collaborate with various different functions each entity or party has, more upgraded logistics services can be given to its users like shipper or producer who has been able to gain better quality of logistics services. The things of providing its tools is mentioned in rationalization, unitization and hub and spoke system, which has gone through first, more efficient and effective way of logistics functions, optimized services activities, and systemized service flow of logistics process. Therefore, total logistics services can be made by third party logistics provider combined 
with fourth party logistics provider, utilizing their own inherent logistical functions. However, it is noted on the way of this research of 3th party logistics to achieve total logistics management that it should be investigated into some application of 4th industrial revolution to 3 th party logistics for further study.

\section{References}

Agburu, J., Anza, N. C., \& Akuraun, S. (2017). Effect of outsourcing strategies on the performance of small and medium scale enterprises (SMEs). Journal of Global Entrepreneurship Research, 7(26), 1-34.

Aoteshu, P. (2019). Logistics Industry News. The meaning of rationalization of logistics transportation. Retrieved October, 22, 2019, from https://www.otsrack.com/news/the-meaning-of-rationalization-of-logistics-tr14672148.html.

Bask, A. (2001). Relationships among TPL providers and members of supply chains - a strategic perspective. The Journal of Business and Industrial Marketing, 16(6), 470-486.

Berglund, M., Laarhoven, P., Sharman, G., \& Wandel, S. (1999). Third-Party logistics: is there a future?. The International Journal of Logistics Management, 10(1), 59-70.

Whale, B. (2019). Simplifying Shipping. Unitization and Containerization. Retrieved October, 12, 2019, from http:// www.blue-whale.in/containers/unitization-and-containerization.

Cheng, Jao-Hong. (2008). A study of constructing fourth party logistics' selection criterion from supply chain integration and information technology perspectives - An application of fuzzy MCDM. Electronic Commerce Studies, 6(4), 401-424.

Copacino, W. (2001). 3PL's narrow the gap. Logistics Management \& Distribution Report, 40(3), 36-36.

Dollet, J. N., \& Diaz, A. (2011). Supply chain orchestration for the luxury alcoholic beverage sector. The IUP Journal of Supply Chain Management, 13(3), 42-65.

Ecer, F. (2018). Third-party logistics (3PLs) provider selection via fuzzy AHP and EDAS integrated model. Technological \& Economic Development of Economy, 24(2). 615-634.

Giustiniano, L., \& Carli, G. L. (2013). The impact of outsourcing on business performance: an empirical analysis. Journal of Modern Accounting and Auditing, 9(2), 153-168.

Hansen, M., Müller, S. H., \& Pottenger, E. (2008). Towards a developing country firm perspective on outsourcing. Strategic Outsourcing: An International Journal, 1(3), 210 - 229.

Hingley, M., Lindgreen, A., Grant, D., \& Kane, C. (2011). Using fourth-party logistics management to improve horizontal collaboration among grocery retailers. Supply Chain Management: An International Journal, 16(5), 316-327.

Huang, B. L. (2001). Enterprise outsourcing strategies and challenges. e-Business Executive Report, 18(1). 12-21.

Huang, F., Shi, X. L., \& Dai, X. Z. (2008). Research on 3PL resource integration mode in Zhejiang province. Logistics Technology, 27(2), 25-28.

Iqbal, Z., \& Dad, M. A (2013). Outsourcing: a review of trends, winners \& losers and future directions. International Journal of Business and Social Science, 4(8), 91-107.

Kao, C. K., Qian, M., Chang, T. H., \& Lin, P. J. (2019). Strategic planning for transitioning from third to fourth party logistics under E-commerce environment in China. International Journal of Organizational Innovation, $12(1), 25-41$.

Li, J., Liu, Y., \& Hu, Z. (2014). Routing optimization of fourth party logistics with reliability constraints based on messy GA. Journal of Industrial Engineering and Management, 7(5), 1097-1111.

Magill, P. (2000). Outsourcing logistics: the transition to 4th party partnership in Europe. Informa UK Limited, First edition. Marino, G. (2002). The ABCs of 4PLs, IIE Solutions, 44(1), 23-23.

PENSKE (2019). PENSKE Logistics. increase efficiency by embracing the hub-and-spoke model. embrace the huband-spoke model. Retrieved October, 27, 2019, from https://www. penskelogistics.com/industries/automo tive/hub-and-spoke.

Ploos, A. M. \& Verstegen, M. F. (1991). Development of a total logistics concept: a method for improving logistics performance. International Journal of Logistics Management, 2(2), 63-73.

Research \& Markets (2019). Logistics market: global industry trends, share, size, growth, opportunity and forecast 2019-2024. Research and Markets, IMARC Group, 1(2), 1-5.

Saglietto, L. (2013). Towards a classification of fourth party logistics (4PL). Universal Journal of Industrial and Business Management, 1(3), 104-116,

Skender, P. H., Mirković, P. A., \& Prudky, I. (2017). The role of the 4PL model in a contemporary supply chain. 
Scientific Journal of Maritime Research, 3(1), 96-101.

Srishti, G., \& Nasina, J. (2019). Selecting a logistics service provider for a manufacturing firm: issues and suggestions. IUP Journal of Supply Chain Management, 16(2), 68-79.

Tu, V. B.4 (2016). Factors impacting on the selection of third party logistics provider. China-USA Business Review, 15(12), 616-627. 